\section{RMD Open}

Rheumatic \&

Musculoskeletal Diseases

To cite: Rios Rodriguez V, Poddubnyy D. Old and new treatment targets in axial spondyloarthritis. RMD Open 2015;1:e000054. doi:10.1136/rmdopen-2015000054

- Prepublication history for this paper is available online. To view these files please visit the journal online (http://dx.doi.org/10.1136/ rmdopen-2015-000054).

Received 16 February 2015 Revised 31 March 2015 Accepted 5 April 2015
CrossMark

Rheumatology, Medical Department I, Charité Universitätsmedizin Berlin, Berlin, Germany

Correspondence to Dr Denis Poddubnyy; denis. poddubnyy@charite.de

\title{
Old and new treatment targets in axial spondyloarthritis
}

Valeria Rios Rodriguez, Denis Poddubnyy

\section{ABSTRACT}

Two main treatment targets in axial spondyloarthritis (axSpA) could be currently defined: (1) reduction of inflammation resulting in control of signs and symptoms such as pain and stiffness and (2) prevention or retardation of structural damage progression in the spine resulting in preservation of functional status and improvement in the long-term outcome. A good control of signs and symptoms could be successfully achieved nowadays in the majority of patients treated with non-steroidal antiinflammatory drugs (NSAIDs-the first-line therapy in axSpA) and with tumour necrosis factor (TNF) $\alpha$ blockers (the second-line therapy, if NSAIDs fail). Several pipeline drugs including interleukin (IL) 17 and IL-23 antagonists might be helpful in the immediate future in achievement of this treatment target in case of inefficacy of NSAIDs and TNF $\alpha$ blockers. Retardation of radiographical spinal progression in axSpA-disease modification-is currently a much more challenging task than a good symptom control. In this review, we discuss symptomatic and possible disease-modifying properties of current and forthcoming treatment options for axSpA.

\section{INTRODUCTION}

Axial spondyloarthritis (axSpA) is an umbrella term for a group of chronic inflammatory rheumatic diseases with primary involvement of the axial skeleton (sacroiliac joints and spine). ${ }^{1}$ Depending on the presence or absence of definite radiographic sacroiliitis (grade II and higher, bilaterally, or grade III and higher, unilaterally ${ }^{2}$ ), two major subtypes of axSpA are defined: nonradiographic axSpA (without definite radiographic sacroiliitis) and radiographic axSpA, also referred to as ankylosing spondylitis (AS). AxSpA is characterised by the presence of active inflammation in the sacroiliac joints and in the spine, especially at the early stage, which manifests as pain and stiffness, and by new bone formation (leading to bony ankylosis) in the same areas that might result in severe limitation of spinal mobility and functional impairment. ${ }^{3}$
Over the past years, the strategies for management and therapy of patients with axSpA have changed substantially. Despite all the advances, there was until recently no clear definition of therapeutic targets and strategies to achieve such targets. The importance of this process can be seen in the case of rheumatoid arthritis (RA). In 2010, treatment targets for RA were clearly defined, specifically remission or low disease activity bringing improved outcomes. ${ }^{4}$ Recently, consensual recommendations for defining a treatment target to improve the management of axial and peripheral $\mathrm{SpA}$ in clinical practice have been developed. According to these recommendations, the primary goal of treatment of $\mathrm{SpA}$ is "to maximize long-term health related quality of life and social participation through control of signs and symptoms, prevention of structural damage, normalization or preservation of function, avoidance of toxicities and minimization of comorbidities." 5 Therefore, the key treatment targets in axSpA could be defined as inflammation and new bone formation; reduction of inflammation would lead to a control of signs and symptoms (pain and stiffness) as well as objective inflammation parameters $(\mathrm{G}$ reactive protein-CRP and osteitis detected on MRI, which, however, are considered secondary to a good symptom $\operatorname{control}^{6}$ ), while prevention of new bone formation would mean disease modification and improvement of the long-term outcome including preserved functional status. This article reviews existing treatment options and evidence related to new treatment strategies in the target areas of inflammation and new bone formation in axSpA.

\section{INFLAMIMATION AS A TREATMENT TARGET Current treatments \\ Non-steroidal anti-inflammatory drugs}

On the basis of the joint Assessment of Spondyloarthritis International Society (ASAS)/ European League Against Rheumatism 
(EULAR) recommendations, the first-line therapy in AS (that could be generalised to axSpA) comprises nonsteroidal anti-inflammatory drugs (NSAID) in conjunction with patient education and regular exercise. ${ }^{6}$ Efficacy of NSAIDs, including the selective cyclooxygenase-2 (COX-2) antagonists, in reduction of pain and stiffness in AS has been proven in a number of studies. $^{7-9}$ There is often a clear improvement of low back pain in patients with AS treated with NSAIDs, with a clinically significant response in more than $70 \%$ of the patients, compared with patients with mechanical back pain, who experienced an improvement in only about $15 \%$ of the cases. ${ }^{10}$ Moreover, NSAIDs have also been shown to be effective even in achieving remission in patients with axSpA, especially for those with short symptom duration. Recently, encouraging results have been observed in the Infliximab as First Line Therapy in Patients with Early Active Axial Spondyloarthritis Trial (INFAST) where patients with axSpA (both radiographic and non-radiographic axSpA) and symptom duration of up to 5 years treated with a combined therapy of tumour necrosis factor (TNF) blocker + NSAID (infliximab + naproxen) were compared with those treated with NSAID (naproxen) alone. While the ASAS partial remission rate at week 28 was achieved by $61.9 \%$ of the patients in the combined therapy group, the remission rate in the naproxen group was surprisingly high at $35.3 \% .{ }^{11}$ Beyond clear symptomatic efficacy, there is some evidence indicating a reduction in objective signs of inflammation in axSpA under NSAIDs therapy: serum level of CRP ${ }^{9}$ and osteitis in the sacroiliac joints and/or spine on MRI. ${ }^{11}$ These data suggest that good symptomatic efficacy of NSAIDs in axSpA is related not only to analgesic properties, but also to their anti-inflammatory properties.

\section{TNF $\alpha$ blockers}

Currently, TNF $\alpha$ blocking therapy is the only effective treatment available to patients with axSpA who are unresponsive to the first-line therapy with NSAIDs. ${ }^{6}{ }^{12}$ According to ASAS recommendations, patients fulfilling the ASAS classification criteria for axSpA ${ }^{13}$ (including patients fulfilling the modified New York criteria for AS), whose disease activity remains high despite the use of NSAIDs, are candidates for the TNF $\alpha$ blocking therapy. ${ }^{12}$

Each of the currently available TNF blocker agents (adalimumab, certolizumab pegol, etanercept, golimumab and infliximab) has a strong and similar clinical efficacy in active AS with a clear improvement of symptoms measured by the ASAS40 response achieved by $40-50 \%$ of treated patients, or by the $50 \%$ improvement of the Bath Ankylosing Spondylitis Disease Activity Index (BASDAI) achieved by $50-60 \%$ of patients, as well as a substantial reduction of active inflammation on MRI. ${ }^{14-18}$ Shorter disease duration, younger age, better functional status, raised CRP and active inflammation on MRI are predictors of a good clinical response. ${ }^{19-21}$ Most recently, all anti-TNF agents (except infliximab) have been investigated in patients with non-radiographic axSpA (which is widely considered as an early stage of AS) with good clinical efficacy similar to that observed earlier in AS trials. ${ }^{18}{ }^{22-24}$ Good clinical efficacy (significantly better than in the placebo group) was, however, observed only in patients with objective signs of inflammation (elevated CRP, osteitis on MRI). Subsequently, the presence of objective signs of inflammation is a pre-requisite for administration of TNF blockers in patients with clinically active non-radiographic axSpA not responding to NSAIDs (currently approved in the European Union are adalimumab, certolizumab pegol and etanercept, while golimumab is likely to be approved in 2015; none of them are approved for non-radiographic axSpA in the USA). According to the current evidence, patients with nr-axSpA without objective signs of inflammation (normal CRP, no osteitis on MRI) are unlikely to benefit from the therapy with TNF blockers.

\section{Other therapies}

Despite the fact that NSAIDs and TNF antagonists significantly improve the outcomes in patients with axSpA, up to $40 \%$ of patients (according to the data from pivotal clinical trials) with active axSpA do not reach a clinically significant response. The majority of treatment options available and effective in RA, for instance, have also been tested in AS/axSpA over the past 10 years.

Conventional disease-modifying antirheumatic drugs like methotrexate, leflunomide and sulfasalazine were found to be generally ineffective for axial manifestations in AS/axSpA, but could have some effect in patients with peripheral joint involvement. ${ }^{25-27}$

The long-term use of systemic glucocorticoids is not recommended in axSpA because there was nearly no evidence of the efficacy of this drug class at the time point of the last revision of the ASAS/EULAR treatment recommendations. ${ }^{6}$ However, in a small, open-label clinical trial, a short-term treatment with intravenous pulse of methylprednisolone was successful in reducing symptoms and improving spinal mobility in active $\mathrm{AS}^{28}$ A recent placebo-controlled study suggests that $50 \mathrm{mg}$ oral prednisolone given daily for 2 weeks could be helpful in treating patients with active AS refractory to NSAIDs treatment. ${ }^{29}$ This indicates that a short-term therapy of oral prednisolone could be considered as an option (or a bridge therapy) for patients with active AS/ axSpA if anti-TNF therapy could not be started immediately. Local steroids are often considered for treatment of peripheral manifestations like enthesitis or arthritis ${ }^{6}$ and have been beneficially used in the past for treatment of active sacroiliitis. ${ }^{30} 31$

Histological studies have observed the important presence of dense infiltrations of B cells in the subchondral bone marrow found in active sacroiliitis. ${ }^{32} 33$ On the basis of these findings, a pilot open-label clinical trial with rituximab (monoclonal anti-CD20 antibodydepleting B cells) was recently performed in patients with active AS. Rituximab was not found to be effective 
in patients who failed previous anti-TNF therapy, but there was some effect in anti-TNF naive patients. Importantly, prior to the rituximab infusion at baseline, all patients received premedication including steroids, which might also have had an impact on clinical symptoms of AS. Unfortunately, no further clinical studies were conducted in order to confirm results from this pilot trial; therefore, the efficacy of rituximab in AS/ axSpA still remains undetermined. ${ }^{34}$

The dominancy of $\mathrm{T}$ cells and macrophages in the inflammatory infiltrates in early active sacroiliitis suggests a specific cellular immune response. ${ }^{35}$ Abatacept is a fusion protein of the extracellular domain of CTLA-4 and an immunoglobulin with a modified Fc, which modulates the co-stimulatory signal required for full T-cell activation. Several case reports and a pilot open-label clinical trial in AS have presented a poor clinical response concluding that abatacept cannot be recommended for the treatment of AS/axSpA. ${ }^{36} 37$

Interleukin (IL) 1 is a proinflammatory cytokine that intervenes in the activation of macrophages and osteoclasts and induces fibroblast proliferation, causing chronic inflammation and bone resorption. Suppression of IL-1 with an IL-1 receptor antagonist (anakinra) decreases inflammation and bone resorption in RA. ${ }^{38}$ Unfortunately, the data from a pilot clinical trial did not show convincing results for patients with active AS. ${ }^{39}$

IL-6 is also a proinflammatory cytokine that was found to be elevated in serum in patients with AS with correlations with disease activity. ${ }^{40}$ Infliximab treatment decreases IL-6 serum levels in patients with AS and this depletion correlated with improvement in disease activity and bone mineral density. ${ }^{41}$ These findings resulted in an assumption that IL-6 suppression might be a possible therapy target in AS/axSpA. Tocilizumab, a humanised monoclonal antibody against IL- 6 receptor- $\alpha$ (IL-6R $\alpha$ ), and sarilumab, a fully human monoclonal antibody against IL-6R $\alpha$, have both demonstrated negative results without a clinically significant effect in patients with active AS refractory or intolerant to NSAIDs. $^{42} 43$

\section{Possible future therapies}

Th17 pathway (IL-17 and IL-23) blockade

The Th17 pathway is implicated in the physiopathology of several chronic inflammatory diseases including RA, psoriasis/psoriatic arthritis and SpA. ${ }^{44-46}$ A Th17 T-cell subset is characterised by IL-17 production and directly related to the induction of tissue inflammation and autoimmunity. ${ }^{47}$ In axSpA, the unfolded protein response (linked to the particular formation of HLA-B27 heavy chains) is believed to result in production of IL-23 by dendritic cells that might activate the Th17 axis that leads to overexpression of proinflammatory cytokines including IL-17 and TNF by the effector cells. ${ }^{48} 49$ The Th17 pathway opens relevant and realistic new therapeutic targets for the treatment of axSpA.
It has been suggested that IL-17 might be a crucial mediator of inflammation in axSpA. ${ }^{44}$ Several studies have demonstrated increased levels of IL-17 in serum and a high number of circulating polyfunctional Th17 cells. ${ }^{50-53}$ Additionally, an immunohistological analysis of IL-17-secreting cells in facet joints from patients with AS indicated that the IL-17-producing cells were significantly higher compared with spine samples obtained from patients with osteoarthritis. ${ }^{54}$ At the moment, there are several molecules blocking IL-17 under investigation: secukinumab, ixekizumab (monoclonal antibodies directed against IL-17A) and brodalumab (a monoclonal antibody against the IL-17 receptor). From these three agents, only secukinumab has so far been tested in AS. In a proof-of-concept clinical trial in patients with active AS, $60 \%$ of patients in the secukinumab group (given as two doses of $10 \mathrm{mg} / \mathrm{kg}$ intravenously 3 weeks apart) reached the primary end point of ASAS20-response at week 6 , indicating a $99.8 \%$ probability of superiority versus placebo. ${ }^{55}$ Results of two phase III clinical trials (MEASURE 1 and MEASURE 2), in which patients with active AS (majority-without previous TNF exposure) were treated with secukinumab, were recently presented in the abstract form. In MEASURE 1, patients received secukinumab $10 \mathrm{mg} / \mathrm{kg}$ intravenously (weeks 0,2 and 4) followed by subcutaneous secukinumab 75 or $150 \mathrm{mg}$ every 4 weeks or placebo. The study met its primary end point with a significantly higher ASAS20 response rate at week 16 of $59.7 \%$ and $60.8 \%$ in the secukinumab 75 and $150 \mathrm{mg}$ groups, respectively, as compared with placebo $\left(28.7 \%, \mathrm{p}<0.01\right.$ vs active treatment).$^{56}$ In the MEASURE 2 study, patients were treated with subcutaneous sekukinumab $75 \mathrm{mg}$ or $150 \mathrm{mg}$ weekly for 4 weeks followed by dosing every 4 weeks or placebo. The primary end point-ASAS20-response at week 16-was achieved in the $150 \mathrm{mg}$ group only: $61.1 \%$ (vs $27 \%$ in the placebo group, $\mathrm{p}=0.001) .{ }^{48}$ Beyond axSpA, secukinumab was clinically effective in clinical trials in psoriasis ${ }^{42}$ and in psoriatic arthritis ${ }^{57}$ but provided negative results in patients with active Crohn's disease (secukinumab treatment was even associated with worse outcome as compared with placebo) $;^{24}$ these results have raised some safety concerns on secukinumab therapy in axSpA due to a well-known association of axSpA with inflammatory bowel disease, which might have a subclinical course prior to the start of IL-17-blocking therapy.

Ixekizumab has shown efficacy in psoriasis, ${ }^{58}$ and further studies in psoriasis and psoriatic arthritis are currently ongoing. Brodalumab has also been successfully tested in phase II trials in psoriasis ${ }^{54}$ and psoriatic arthritis. ${ }^{59}$ It is most likely that phase II/III trials in AS/axial SpA with ixekizumab and brodalumab will follow soon considering the positive results of the secukinumab programme.

Efficacy of IL17 blockade in the entire population of axSpA including the non-radiographic form, efficacy in patients non-responding to anti-TNF therapy, and efficacy regarding retardation of structural damage progression in the spine should be addressed in future studies. 
Another potential therapeutic target in axSpA interfering with the Th17 axis could be the blockade of IL-23. IL-23, together with transforming growth factor (TGF) $-\beta$ and IL- 6 , is essential for the differentiation and activation of Th17 lymphocytes. ${ }^{4760} 61$ Indeed, the presence of IL-23 is crucial to maintain the Th17 phenotype and achieve full effector function. ${ }^{62}$ IL-23 consists of two subunits: p40, which is also present in IL-12, and p19, which is specific for IL-23. Several studies described elevated concentrations of IL-23 in serum and synovial fluid from patients with $\mathrm{AS}^{50} 63$ and found that the number of IL-23p19+ cells in the bone marrow of facet joints of patients with AS was significantly higher compared with the samples obtained from patients with osteoarthritis and individuals without spinal disease. ${ }^{64}$ Furthermore, IL-23 was found to be essential for the induction of specific SpA-like entheseal inflammation in vivo in a mouse model. ${ }^{65}$

Ustekinumab, a monoclonal antibody directed against the common p40 subunit of IL-23 and IL-12, has been recently approved for the treatment of psoriasis and psoriatic arthritis. The recently published results from a proof-of-concept trial with ustekinumab in patients with active AS and an inadequate response to NSAIDs are encouraging. In this open-label trial, ustekinumab was administered in a dose of $90 \mathrm{mg}$ subcutaneous at weeks 0,4 and 16. The ASAS40 response at week 24 (the primary outcome) was achieved by $65 \%$ of patients. ${ }^{66}$ The promising results should be confirmed in a placebocontrolled trial.

Several specific inhibitors of IL-23 (monoclonal antibodies against the p19 subunit)-BI 655066, guselkumab and tildrakizumab-are underway now in clinical trials in psoriasis (ClinicalTrials.gov identifiers NCT02203851, NCT02207244 and NCT01729754), psoriatic arthritis (NCT02319759), while BI 655066 in also being currently investigated in a phase II study in AS (NCT02047110).

\section{Phosphodiesterase 4 blockade}

Given that cytokines such as TNF $\alpha$, IL-23, IL-17 and IL-10, influenced by PDE4 (phosphodiesterase 4), play an important role in SpA, a pilot study of a small molecule-specific PDE4 inhibitor (apremilast, currently approved for treatment of psoriasis and psoriatic arthritis) in AS was performed. ${ }^{67}$ Although the primary end point BASDAI at week 12 was not met, a phase III clinical trial (POSTURE, NCT01583374) was initiated to evaluate apremilast efficacy and safety. The primary end point of the POSTURE study (ASAS20 at week 16) was not met; however, based on the decision of the Data Monitoring Committee, the study was continued without change. ${ }^{68}$

\section{Janus-kinase blockade}

Tofacitinib is a substance inhibiting Janus-kinases (JAK) 1 and 3 in vivo, which have a pivotal role in cytokine signal transduction that regulates lymphocyte proliferation, differentiation and apoptosis. Tofacitinib has proven to be effective in rheumatoid arthritis ${ }^{69}$ and potentially might be also effective for AS/axSpA. Currently, there is an ongoing phase II study with patients with active AS (NCT01786668); no data are as yet available.

\section{Dual variable domain immunoglobulin}

A novel therapeutic class in autoimmune diseases is the DVD-Ig (dual variable domain immunoglobulin), which is a new type of dual-specific immunoglobulin. The DVD-Ig protein is unique in that each arm of the molecule contains two variable domains that can have different binding specificities. ${ }^{70}$ ABT-122, which is the new DVD-Ig molecule targeting both human TNF and IL-17 cytokines, is currently under investigation in phase I/II clinical trials, ${ }^{71}$ NCT02349451. Dual blockade of TNF and IL-17 might be especially effective in axSpA and other SpAs considering a crucial role of both cytokines in the pathogenesis of these conditions. Further studies should also address concerns related to the safety of the dual blockade of TNF and IL-17.

\section{NEW BONE FORMATION AS A TREATIMENT TARGET}

As already mentioned, axSpA is a chronic inflammatory rheumatic disease that affects the axial skeleton. According to the current understanding of the disease, active inflammation in the sacroiliac joints and in the spine is followed by the process of bone repair leading to excessive new bone formation-a morphological substrate of structural damage in axSpA. ${ }^{72}$ While new bone formation/ankylosis in the sacroiliac joints has a diagnostic value only without a significant impact on the patient's functional status, new bone formation in the spine (syndesmophytes, bridging syndesmophytes, ankylosis) has a clear correlation with reduction of spinal mobility and functional status in patients with axSpA. ${ }^{3} 73$ Therefore, drugs with a proven effect on progression of structural damage in the spine would possess a diseasemodifying property in axSpA.

NSAIDs might have an impact on the progression of structural damage in the spine. Boersma described for the first time in 1976 that a continuous therapy with phenylbutazone could have an inhibitory effect on the progression of ossification of the spine in patients with AS. ${ }^{74}$ Years later, the association of NSAIDs therapy and retardation of radiographic spinal progression was found in a study performed by Wanders et al. This study compared the radiographic progression between continuous daily use of NSAIDs (in the majority of patients, celecoxib-a selective COX-2 inhibitor) and the use of NSAIDs only on demand. The authors concluded that although both strategies presented a similar effect on symptoms and signs, the continuous NSAIDs treatment significantly reduced the progression of structural damage. ${ }^{75}$ Recently, data from the GErman SPondyloarthritis Inception Cohort (GESPIC) provided 
similar results. In this cohort, patients with AS with high NSAIDs intake (defined as $\geq 50 \%$ of the maximal recommended dose) over 2 years had a lower radiographic spinal progression rate compared with patients with low NSAIDs intake. This protective effect was nearly exclusively seen in patients with AS with syndesmophytes at baseline and elevated CRP-known risk factors for radiographic spinal progression in $\operatorname{axSpA}^{76}$-suggesting that continuous NSAIDs treatment might be especially beneficial in patients with these characteristics. ${ }^{77}$ Similar data were also found in a post hoc analysis of the previously referenced study by Wanders et al: retardation of radiographic spinal progression due to continuous intake of NSAIDs was observed only in patients with elevated CRP. ${ }^{78}$ Despite these positive results, there is still a need for confirmation of these data in another randomised controlled trial. Furthermore, the role of COX-2-selectivity for inhibition of new bone formation in the spine is still not clear. Also, the effect of a combined therapy with an NSAID plus a TNF blocker on radiographic spinal progression in AS/axSpA is not known. Therefore, taking all risks and possible benefits of NSAIDs into account, the indications for NSAIDs therapy in daily clinical practice should currently be determined by the presence or absence of clinical symptoms (pain, stiffness) of $\operatorname{axSpA}^{6}$ rather than by the presence of risk factors of radiographic spinal progression.

Despite their strong anti-inflammatory efficacy, TNF blockers (adalimumab, etanercept, golimumab and infliximab) did not show retardation on radiographic progression during 2 years (or even 4 years for golimumab) of therapy in advanced AS. ${ }^{79-82}$ However, a longer treatment (over 6-8 years) might be associated with reduced radiographic spinal progression, as indicated in a relatively recent small long-term study with infliximab. ${ }^{83}$

Recently, Maksymowych et al have proposed the TNF brake hypothesis, which proposes an explanation for the possible different effects of anti-TNF therapy on structural damage in the spine in early and advanced disease. The hypothesis suggests that early inflammatory lesions resolve without sequel if the treatment is started before the bone formation pathways get activated; if the lesion is mature and bone formation pathways are triggered, TNF may act as a brake on the new bone formation process while TNF blockade would release this brake. ${ }^{84}$ This hypothesis indicates the possible existence of a 'window of opportunity' in axSpA-a certain time period (first months to years of the disease) in which resolution of inflammation due to TNF blockade would not lead to activation of new bone formation in the spine later on. A recent study by Haroon $e t a l^{85}$ indicated that initiation of anti-TNF therapy within the first 10 years since symptom onset of AS was associated with less radiographic spinal progression as compared to patients with later start of the therapy supporting the 'window of opportunity' hypothesis. Whether novel drugs such as IL-17, IL-23 blockers and 'small molecules' (apremilast, tofacitinib) are able to retard radiographic spinal progression has yet to be determined.

\section{CONCLUSION}

Current treatment options allow good control of symptoms-the primary treatment aim in axSpA nowadaysin the majority of patients. Novel treatments including IL-17 and IL-23 inhibitors might be a further treatment option for patients not responding adequately to the first-line (NSAIDs) and second-line (TNF blockers) treatment. Currently available data indicating possible disease-modifying properties of NSAIDs and TNF blockers by inhibition of progression of structural damage in the spine still require confirmation.

Competing interests DP received consulting and speaking fees from Abbvie, Bristol-Myers Squibb, Janssen Cilag, MSD, Novartis, Pfizer, Roche and UCB.

Provenance and peer review Commissioned; externally peer reviewed.

Data sharing statement No additional data are available.

Open Access This is an Open Access article distributed in accordance with the Creative Commons Attribution Non Commercial (CC BY-NC 4.0) license, which permits others to distribute, remix, adapt, build upon this work noncommercially, and license their derivative works on different terms, provided the original work is properly cited and the use is non-commercial. See: http:// creativecommons.org/licenses/by-nc/4.0/

\section{REFERENCES}

1. Rudwaleit M, van der Heijde D, Landewe R, et al. The Assessment of SpondyloArthritis International Society classification criteria for peripheral spondyloarthritis and for spondyloarthritis in general. Ann Rheum Dis 2011;70:25-31.

2. van der Linden S, Valkenburg HA, Cats A. Evaluation of diagnostic criteria for ankylosing spondylitis. A proposal for modification of the New York criteria. Arthritis Rheum 1984;27:361-8.

3. Landewe $\mathrm{R}$, Dougados $\mathrm{M}$, Mielants $\mathrm{H}$, et al. Physical function in ankylosing spondylitis is independently determined by both disease activity and radiographic damage of the spine. Ann Rheum Dis 2009;68:863-7.

4. Sieper J, Porter-Brown B, Thompson L, et al. Assessment of short-term symptomatic efficacy of tocilizumab in ankylosing spondylitis: results of randomised, placebo-controlled trials. Ann Rheum Dis 2014;73:95-100.

5. Smolen JS, Braun J, Dougados M, et al. Treating spondyloarthritis, including ankylosing spondylitis and psoriatic arthritis, to target: recommendations of an international task force. Ann Rheum Dis 2014;73:6-16.

6. Braun J, van den Berg R, Baraliakos X, et al. 2010 update of the ASAS/EULAR recommendations for the management of ankylosing spondylitis. Ann Rheum Dis 2011;70:896-904.

7. Dougados M, Gueguen A, Nakache JP, et al. Ankylosing spondylitis: what is the optimum duration of a clinical study? A one year versus a 6 weeks non-steroidal anti-inflammatory drug trial. Rheumatology (Oxford) 1999;38:235-44

8. van der Heijde D, Baraf HS, Ramos-Remus C, et al. Evaluation of the efficacy of etoricoxib in ankylosing spondylitis: results of a fifty-two-week, randomized, controlled study. Arthritis Rheum 2005;52:1205-15.

9. Sieper J, Klopsch T, Richter M, et al. Comparison of two different dosages of celecoxib with diclofenac for the treatment of active ankylosing spondylitis: results of a 12-week randomised, double-blind, controlled study. Ann Rheum Dis 2008;67:323-9.

10. Amor B, Dougados M, Listrat V, et al. Are classification criteria for spondylarthropathy useful as diagnostic criteria? Rev Rhum Engl Ed 1995;62:10-15.

11. Sieper J, Lenaerts J, Wollenhaupt J, et al. Efficacy and safety of infliximab plus naproxen versus naproxen alone in patients with early, active axial spondyloarthritis: results from the double-blind, placebo-controlled INFAST study, Part 1. Ann Rheum Dis 2014;73:101-7. 
12. van der Heijde D, Sieper J, Maksymowych WP, et al. 2010 Update of the international ASAS recommendations for the use of anti-TNF agents in patients with axial spondyloarthritis. Ann Rheum Dis 2011;70:905-8.

13. Rudwaleit M, van der Heijde D, Landewe R, et al. The development of Assessment of SpondyloArthritis international Society classification criteria for axial spondyloarthritis (part II): validation and final selection. Ann Rheum Dis 2009;68:777-83.

14. van der Heijde D, Dijkmans B, Geusens P, et al. Efficacy and safety of infliximab in patients with ankylosing spondylitis: results of a randomized, placebo-controlled trial (ASSERT). Arthritis Rheum 2005;52:582-91.

15. Davis JC, van der Heijde DM, Braun J, et al. Sustained durability and tolerability of etanercept in ankylosing spondylitis for 96 weeks. Ann Rheum Dis 2005;64:1557-62.

16. van der Heijde D, Kivitz A, Schiff MH, et al. Efficacy and safety of adalimumab in patients with ankylosing spondylitis: results of a multicenter, randomized, double-blind, placebo-controlled trial. Arthritis Rheum 2006;54:2136-46.

17. Inman RD, Davis JC Jr, Heijde D, et al. Efficacy and safety of golimumab in patients with ankylosing spondylitis: results of a randomized, double-blind, placebo-controlled, phase III trial. Arthritis Rheum 2008:58:3402-12.

18. Landewe R, Braun J, Deodhar A, et al. Efficacy of certolizumab pegol on signs and symptoms of axial spondyloarthritis including ankylosing spondylitis: 24-week results of a double-blind randomised placebo-controlled Phase 3 study. Ann Rheum Dis 2014;73:39-47.

19. Rudwaleit M, Schwarzlose S, Hilgert ES, et al. MRI in predicting a major clinical response to anti-tumour necrosis factor treatment in ankylosing spondylitis. Ann Rheum Dis 2008;67:1276-81.

20. Rudwaleit M, Claudepierre $\mathrm{P}$, Wordsworth $\mathrm{P}$, et al. Effectiveness, safety, and predictors of good clinical response in 1250 patients treated with adalimumab for active ankylosing spondylitis. J Rheumatol 2009;36:801-8.

21. Vastesaeger N, van der Heijde D, Inman RD, et al. Predicting the outcome of ankylosing spondylitis therapy. Ann Rheum Dis 2011;70:973-81.

22. Sieper J, van der Heijde D, Dougados M, et al. Efficacy and safety of adalimumab in patients with non-radiographic axial spondyloarthritis: results of a randomised placebo-controlled tria (ABILITY-1). Ann Rheum Dis 2013;72:815-22.

23. Dougados M, van der Heijde D, Sieper J, et al. Symptomatic efficacy of etanercept and its effects on objective signs of inflammation in early nonradiographic axial spondyloarthritis: a multicenter, randomized, double-blind, placebo-controlled trial. Arthritis Rheumatol 2014;66:2091-102.

24. Sieper J, van der Heijde D, Dougados $\mathrm{M}$, et al. A randomized, double-blind, placebo-controlled, 16-week study of subcutaneous golimumab in patients with active nonradiographic axial spondyloarthritis. Arthritis Rheum 2014;66:S1283.

25. Braun J, Zochling J, Baraliakos X, et al. Efficacy of sulfasalazine in patients with inflammatory back pain due to undifferentiated spondyloarthritis and early ankylosing spondylitis: a multicentre randomised controlled trial. Ann Rheum Dis 2006;65:1147-53.

26. Haibel H, Rudwaleit M, Braun J, et al. Six months open label trial of leflunomide in active ankylosing spondylitis. Ann Rheum Dis 2005;64:124-6.

27. Haibel $\mathrm{H}$, Brandt $\mathrm{HC}$, Song $\mathrm{IH}$, et al. No efficacy of subcutaneous methotrexate in active ankylosing spondylitis: a 16-week open-label trial. Ann Rheum Dis 2007;66:419-21.

28. Peters ND, Ejstrup L. Intravenous methylprednisolone pulse therapy in ankylosing spondylitis. Scand J Rheumatol 1992;21:134-8.

29. Haibel H, Fendler C, Listing J, et al. Efficacy of oral prednisolone in active ankylosing spondylitis: results of a double-blind, randomised, placebo-controlled short-term trial. Ann Rheum Dis 2014;73:243-6.

30. Braun J, Bollow M, Seyrekbasan F, et al. Computed tomography guided corticosteroid injection of the sacroiliac joint in patients with spondyloarthropathy with sacroiliitis: clinical outcome and follow up by dynamic magnetic resonance imaging. J Rheumatol 1996;23:659-64.

31. Bollow M, Braun J, Taupitz M, et al. CT-guided intraarticular corticosteroid injection into the sacroiliac joints in patients with spondyloarthropathy: indication and follow-up with contrast-enhanced MRI. J Comput Assist Tomogr 1996;20:512-21.

32. Appel H, Kuhne M, Spiekermann S, et al. Immunohistologic analysis of zygapophyseal joints in patients with ankylosing spondylitis. Arthritis Rheum 2006;54:2845-51.

33. Braun J, Bollow M, Neure L, et al. Use of immunohistologic and in situ hybridization techniques in the examination of sacroiliac joint biopsy specimens from patients with ankylosing spondylitis. Arthritis Rheum 1995;38:499-505.
34. Song IH, Heldmann F, Rudwaleit M, et al. Different response to rituximab in tumor necrosis factor blocker-naive patients with active ankylosing spondylitis and in patients in whom tumor necrosis factor blockers have failed: a twenty-four-week clinical trial. Arthritis Rheum 2010;62:1290-7.

35. Bollow M, Fischer T, Reisshauer $\mathrm{H}$, et al. Quantitative analyses of sacroiliac biopsies in spondyloarthropathies: $T$ cells and macrophages predominate in early and active sacroiliitis cellularity correlates with the degree of enhancement detected by magnetic resonance imaging. Ann Rheum Dis 2000;59:135-40.

36. Song $\mathrm{IH}$, Heldmann F, Rudwaleit M, et al. Treatment of active ankylosing spondylitis with abatacept: an open-label, 24-week pilot study. Ann Rheum Dis 2011;70:1108-10.

37. Song $\mathrm{IH}$, Poddubnyy $\mathrm{D}$. New treatment targets in ankylosing spondylitis and other spondyloarthritides. Curr Opin Rheumatol 2011;23:346-51.

38. Dinarello CA, van der Meer JW. Treating inflammation by blocking interleukin-1 in humans. Semin Immunol 2013;25:469-84.

39. Haibel H, Rudwaleit M, Listing J, et al. Open label trial of anakinra in active ankylosing spondylitis over 24 weeks. Ann Rheum Dis 2005;64:296-8.

40. Visvanathan S, Wagner C, Marini JC, et al. Inflammatory biomarkers, disease activity and spinal disease measures in patients with ankylosing spondylitis after treatment with infliximab. Ann Rheum Dis 2008;67:511-17.

41. Visvanathan S, van der Heijde D, Deodhar A, et al. Effects of infliximab on markers of inflammation and bone turnover and associations with bone mineral density in patients with ankylosing spondylitis. Ann Rheum Dis 2009;68:175-82.

42. Langley RG, Elewski BE, Lebwohl M, et al. Secukinumab in plaque psoriasis-results of two phase 3 trials. $N$ Engl J Med 2014;371:326-38.

43. Sieper J, Braun J, Kay J, et al. Sarilumab for the treatment of ankylosing spondylitis: results of a phase II, randomised, double-blind, placebo-controlled study (ALIGN). Ann Rheum Dis 2015;74:1051-7.

44. Shen H, Goodall JC, Hill Gaston JS. Frequency and phenotype of peripheral blood Th17 cells in ankylosing spondylitis and rheumatoid arthritis. Arthritis Rheum 2009;60:1647-56.

45. Leipe J, Grunke M, Dechant C, et al. Role of Th17 cells in human autoimmune arthritis. Arthritis Rheum 2010;62:2876-85.

46. Kagami S, Rizzo HL, Lee JJ, et al. Circulating Th17, Th22, and Th1 cells are increased in psoriasis. J Invest Dermatol 2010;130: 1373-83.

47. Bettelli E, Korn T, Oukka M, et al. Induction and effector functions of $\mathrm{T}(\mathrm{H}) 17$ cells. Nature 2008;453:1051-7.

48. Sieper J, Braun J, Baraliakos X, et al. Secukinumab, a monoclonal antibody to interleukin-17A, significantly improves signs and symptoms of active ankylosing spondylitis: results of a phase 3 , randomized, placebo-controlled trial with subcutaneous loading and maintenance dosing. Arthritis Rheum 2014;66:S232.

49. Colbert RA, Tran TM, Layh-Schmitt G. HLA-B27 misfolding and ankylosing spondylitis. Mol Immunol 2014;57:44-51.

50. Mei Y, Pan F, Gao J, et al. Increased serum IL-17 and IL-23 in the patient with ankylosing spondylitis. Clin Rheumatol 2011;30:269-73.

51. Wendling D, Cedoz JP, Racadot E, et al. Serum IL-17, BMP-7, and bone turnover markers in patients with ankylosing spondylitis. Joint Bone Spine 2007;74:304-5.

52. Jandus C, Bioley G, Rivals JP, et al. Increased numbers of circulating polyfunctional Th17 memory cells in patients with seronegative spondylarthritides. Arthritis Rheum 2008;58: 2307-17.

53. Wang X, Lin Z, Wei Q, et al. Expression of IL-23 and IL-17 and effect of IL-23 on IL-17 production in ankylosing spondylitis. Rheumatol Int 2009;29:1343-7.

54. Appel H, Maier R, Wu P, et al. Analysis of IL-17(+) cells in facet joints of patients with spondyloarthritis suggests that the innate immune pathway might be of greater relevance than the Th17-mediated adaptive immune response. Arthritis Res Ther 2011;13:R95.

55. Baeten D, Baraliakos X, Braun J, et al. Anti-interleukin-17A monoclonal antibody secukinumab in treatment of ankylosing spondylitis: a randomised, double-blind, placebo-controlled trial. Lancet 2013;382:1705-13.

56. Baeten D, Braun J, Baraliakos X, et al. Secukinumab, a monoclonal antibody to interleukin-17A, significantly improves signs and symptoms of active ankylosing spondylitis: results of a 52-week phase 3 randomized placebo-controlled trial with intravenous loading and subcutaneous maintenance dosing. Arthritis Rheum 2014;66: S360. 
57. Mclnnes IB, Sieper J, Braun J, et al. Efficacy and safety of secukinumab, a fully human anti-interleukin-17A monoclonal antibody, in patients with moderate-to-severe psoriatic arthritis: a 24-week, randomised, double-blind, placebo-controlled, phase II proof-of-concept trial. Ann Rheum Dis 2014;73:349-56.

58. Leonardi C, Matheson R, Zachariae C, et al. Anti-interleukin-17 monoclonal antibody ixekizumab in chronic plaque psoriasis. $N$ Engl J Med 2012;366:1190-9.

59. Strober BE, Crowley JJ, Yamauchi PS, et al. Efficacy and safety results from a phase III, randomized controlled trial comparing the safety and efficacy of briakinumab with etanercept and placebo in patients with moderate to severe chronic plaque psoriasis. $\mathrm{Br} \mathrm{J}$ Dermatol 2011;165:661-8.

60. Harrington LE, Hatton RD, Mangan PR, et al. Interleukin 17-producing CD4+ effector T cells develop via a lineage distinct from the $T$ helper type 1 and 2 lineages. Nat Immunol 2005;6:1123-32.

61. Acosta-Rodriguez EV, Napolitani G, Lanzavecchia A, et al. Interleukins 1 beta and 6 but not transforming growth factor-beta are essential for the differentiation of interleukin 17-producing human $T$ helper cells. Nat Immunol 2007;8:942-9.

62. Matsui M. Roles of the novel interleukin-12-associated cytokine, interleukin-23, in the regulation of T-cell-mediated immunity. Hepatol Res 2007;37(Suppl 3):S310-18.

63. Romero-Sanchez C, Jaimes DA, Londono J, et al. Association between Th-17 cytokine profile and clinical features in patients with spondyloarthritis. Clin Exp Rheumatol 2011;29:828-34.

64. Appel $\mathrm{H}$, Maier R, Bleil J, et al. In situ analysis of interleukin-23- and interleukin-12-positive cells in the spine of patients with ankylosing spondylitis. Arthritis Rheum 2013;65:1522-9.

65. Sherlock JP, Joyce-Shaikh B, Turner SP, et al. IL-23 induces spondyloarthropathy by acting on ROR-gammat+ CD3 +CD4-CD8-entheseal resident T cells. Nat Med 2012;18:1069-76.

66. Poddubnyy D, Hermann KG, Callhoff J, et al. Ustekinumab for the treatment of patients with active ankylosing spondylitis: results of a 28-week, prospective, open-label, proof-of-concept study (TOPAS). Ann Rheum Dis 2014;73:817-23.

67. Pathan E, Abraham S, Van Rossen E, et al. Efficacy and safety of apremilast, an oral phosphodiesterase 4 inhibitor, in ankylosing spondylitis. Ann Rheum Dis 2013;72:1475-80.

68. http://ir.celgene.com/releasedetail.cfm?releaseid=858785 (last accessed 15 Feb 2015).

69. Burmester GR, Blanco R, Charles-Schoeman C, et al Tofacitinib (CP-690,550) in combination with methotrexate in patients with active rheumatoid arthritis with an inadequate response to tumour necrosis factor inhibitors: a randomised phase 3 trial. Lancet 2013;381:451-60.

70. DeLay ML, Turner MJ, Klenk El, et al. HLA-B27 misfolding and the unfolded protein response augment interleukin-23 production and are associated with Th17 activation in transgenic rats. Arthritis Rheum 2009;60:2633-43.

71. Ruzek M, Conlon D, Mansikka H, et al. ABT-122, a novel dual variable domain (DVD)-Ig, targeting TNF and IL-17, inhibits peripheral blood mononuclear cell production of GM-CSF and decreases lymphocyte expression of CXCR4 in healthy subjects. Arthritis Rheum 2014;66:S445-S6.

72. Sieper J, Poddubnyy D. Inflammation, new bone formation and treatment options in axial spondyloarthritis. Ann Rheum Dis 2014;73:1439-41.

73. Machado P, Landewe R, Braun J, et al. Both structural damage and inflammation of the spine contribute to impairment of spinal mobility in patients with ankylosing spondylitis. Ann Rheum Dis 2010;69:1465-70.

74. Boersma JW. Retardation of ossification of the lumbar vertebral column in ankylosing spondylitis by means of phenylbutazone. Scand J Rheumatol 1976;5:60-4.

75. Wanders A, Heijde D, Landewe R, et al. Nonsteroidal antiinflammatory drugs reduce radiographic progression in patients with ankylosing spondylitis: a randomized clinical trial. Arthritis Rheum 2005;52:1756-65.

76. Poddubnyy D, Haibel H, Listing J, et al. Baseline radiographic damage, elevated acute-phase reactant levels, and cigarette smoking status predict spinal radiographic progression in early axial spondylarthritis. Arthritis Rheum 2012;64:1388-98.

77. Poddubnyy D, Rudwaleit M, Haibel H, et al. Effect of non-steroidal anti-inflammatory drugs on radiographic spinal progression in patients with axial spondyloarthritis: results from the German Spondyloarthritis Inception Cohort. Ann Rheum Dis 2012;71:1616-22.

78. Kroon F, Landewe R, Dougados M, et al. Continuous NSAID use reverts the effects of inflammation on radiographic progression in patients with ankylosing spondylitis. Ann Rheum Dis 2012;71:1623-9.

79. van der Heijde D, Landewe R, Baraliakos X, et al. Radiographic findings following two years of infliximab therapy in patients with ankylosing spondylitis. Arthritis Rheum 2008;58:3063-70.

80. van der Heijde D, Landewe R, Einstein S, et al. Radiographic progression of ankylosing spondylitis after up to two years of treatment with etanercept. Arthritis Rheum 2008;58:1324-31.

81. van der Heijde D, Salonen D, Weissman BN, et al. Assessment of radiographic progression in the spines of patients with ankylosing spondylitis treated with adalimumab for up to 2 years. Arthritis Res Ther 2009;11:R127.

82. Braun J, Baraliakos X, Hermann KG, et al. The effect of two golimumab doses on radiographic progression in ankylosing spondylitis: results through 4 years of the GO-RAISE trial. Ann Rheum Dis 2014;73:1107-13.

83. Baraliakos $\mathrm{X}$, Haibel $\mathrm{H}$, Listing J, et al. Continuous long-term anti-TNF therapy does not lead to an increase in the rate of new bone formation over 8 years in patients with ankylosing spondylitis. Ann Rheum Dis 2014;73:710-15.

84. Maksymowych WP, Morency N, Conner-Spady B, et al. Suppression of inflammation and effects on new bone formation in ankylosing spondylitis: evidence for a window of opportunity in disease modification. Ann Rheum Dis 2013;72:23-8.

85. Haroon N, Inman RD, Learch TJ, et al. The impact of tumor necrosis factor alpha inhibitors on radiographic progression in ankylosing spondylitis. Arthritis Rheum 2013;65:2645-54. 